\title{
Epidemiology of Taenia saginata taeniosis/ cysticercosis: a systematic review of the distribution in southern and eastern Africa
}

Veronique Dermauw ${ }^{1 *}$ DD, Pierre Dorny ${ }^{1,2}$, Uffe Christian Braae ${ }^{3}$, Brecht Devleesschauwer $^{4,5}$, Lucy J. Robertson $^{6}$, Anastasios Saratsis ${ }^{7}$ and Lian F. Thomas ${ }^{8,9}$

\begin{abstract}
Background: The beef tapeworm, Taenia saginata, causing cysticercosis in bovines and taeniosis in humans, is thought to have a global distribution. In eastern and southern Africa, cattle production plays a crucial role in the economy, but a clear overview of the prevalence of $T$. saginata in the region is still lacking. This review aims to summarize existing knowledge on $T$. saginata taeniosis and bovine cysticercosis distribution in eastern and southern Africa.
\end{abstract}

Methods: A systematic review was conducted, that gathered published and grey literature, including OIE reports, concerning T. saginata taeniosis and bovine cysticercosis in eastern and southern Africa published between January 1st, 1990 and December 31st, 2017.

Results: A total of 1232 records were initially retrieved, with 78 full text articles retained for inclusion in the database. Unspecified taeniosis cases were reported for Angola, Ethiopia, Kenya, Madagascar, Malawi, South Africa, Tanzania, Uganda and Zambia, whereas T. saginata taeniosis cases were found for Ethiopia, Kenya, South Africa, Tanzania, Zambia and Zimbabwe. The prevalence of taeniosis ranged between $0.2-8.1 \%$ based on microscopy, and between $0.12-19.7 \%$ based on coproAg-ELISA. In Ethiopia, the percentage of tapeworm self-reporting was high (45.0-64.2\%), and a substantial number of anthelmintic treatments were reported to be sold in towns. The presence of bovine cysticercosis was reported in all 27 countries/territories included in the study, except for Rwanda and Somalia, Comoros, Madagascar, Mauritius, Mayotte, Seychelles and Socotra. The prevalence of cysticercosis ranged between 0.02-26.3\% based on meat inspection, and between 6.1-34.9\% based on Ag-ELISA.

Conclusions: Although T. saginata has been reported in the majority of countries/territories of the study area, $T$. saginata taeniosis/cysticercosis remains a largely ignored condition, probably due to the absence of symptoms in cattle, the lack of data on its economic impact, and the fact that human taeniosis is considered a minor health problem. However, the occurrence of bovine cysticercosis is a clear sign of inadequate sanitation, insufficient meat inspection, and culinary habits that may favour transmission. Measures to reduce transmission of $T$. saginata are therefore warranted and the infection should be properly monitored.

Keywords: Taenia saginata, Cestode, Beef tapeworm, Taeniosis, Bovine cysticercosis, Eastern Africa, Southern Africa

\footnotetext{
* Correspondence: vdermauw@itg.be

'Department of Biomedical Sciences, Institute of Tropical Medicine, Antwerp,

Belgium

Full list of author information is available at the end of the article
}

(c) The Author(s). 2018 Open Access This article is distributed under the terms of the Creative Commons Attribution 4.0 International License (http://creativecommons.org/licenses/by/4.0/), which permits unrestricted use, distribution, and reproduction in any medium, provided you give appropriate credit to the original author(s) and the source, provide a link to the Creative Commons license, and indicate if changes were made. The Creative Commons Public Domain Dedication waiver (http://creativecommons.org/publicdomain/zero/1.0/) applies to the data made available in this article, unless otherwise stated. 


\section{Background}

The beef tapeworm, Taenia saginata, utilizes bovines as intermediate hosts and humans as final hosts. Although tapeworm infections have been reported since ancient times [1], it was not until 1782 [2] that differentiation of T. saginata from the other well-known meat-transmitted human tapeworm, Taenia solium, was established. Furthermore, it was not until 1871 that the role of cattle as intermediate hosts for the parasite was established, with "measly" beef being reported as the source of infection in patients [3].

Ingestion of raw or undercooked infected beef is indeed the mode of transmission of this zoonotic parasite to humans, in whom it develops to its adult form, a several metres long segmented worm consisting of a scolex with four suckers, neck and strobila, i.e. a chain of proglottids [4]. In contrast to $T$. solium, the gravid proglottids of $T$. saginata, which contain thousands of embryonated eggs, are mobile and can migrate from the anus independently of, as well as during, defaecation [5]. Eggs are then shed into the environment, and cattle become infected through grazing contaminated pastures, or ingesting contaminated fodder or water. After hatching, and penetration of the intestinal wall, the oncospheres reach the general circulation, distributing them throughout the body where they develop into cysticerci [4]. Common predilection sites for $T$. saginata cysticerci include the heart and masseter muscles [6].

In both intermediate and definitive hosts, $T$. saginata causes few symptoms. In humans, infection is usually characterized by anal pruritus due the active migration of $T$. saginata proglottids and some mild abdominal pain [7]. Nevertheless, the (potential) presence of a tapeworm in the body can cause distress [8], and some people even suffer from a pathological fear of tapeworms, often encouraged by horror stories circulating in popular media or books $[9,10]$. Moreover, although rare, complications due to taeniosis, such as appendicitis, have been reported [11]. In cattle, the infection is generally asymptomatic but nevertheless may incur great economic losses for the meat sector due to carcass condemnation or treatment upon detection of cysticerci during meat inspection, as well as related insurance costs $[12,13]$.

Taenia saginata is distributed globally, with the parasite occurring in both developed and developing countries, although less frequently in countries where cultural preferences limit consumption of bovids or where adequate sanitary infrastructure reduces the likelihood of bovids ingesting human faecal matter. Thus, the prevalence of human taeniosis and bovine cysticercosis are considered particularly high in Africa, Latin America and some parts of Asia [4].

In eastern and southern Africa, the cattle population was estimated at a massive 20.6 million in 2016 [14], so the parasite is thought to be of particular relevance here. In the area, bovines are essential for the livelihoods of smallholders, serving as a source of food, draft power and manure, as well as acting as a financial buffer for challenging times. Although there are indications of the widespread presence of the parasite in at least some countries in this region (e.g. Ethiopia: [15-17]), an extensive overview of its distribution in this region, along with epidemiological considerations regarding its presence, is still lacking. Our aim was therefore to gather recent information on the presence of $T$. saginata in eastern and southern Africa.

\section{Methods}

\section{Search strategy}

A systematic review of published literature was conducted to collect data on the occurrence, prevalence, and geographical distribution of bovine cysticercosis and human taeniosis in eastern and southern Africa, published between January 1st, 1990 and December 31st, 2017. For the purpose of this study, eastern and southern Africa was defined as the area covered by the following countries/territories: Angola, Botswana, Burundi, Comoros, Djibouti, Eritrea, Ethiopia, Kenya, Lesotho, Madagascar, Malawi, Mauritius, Mayotte (French), Mozambique, Namibia, Réunion (French), Rwanda, Seychelles, Socotra (Yemini), Somalia (including the autonomous regions Puntland and Somaliland), South Africa, Swaziland, Tanzania (including the semi-autonomous region of Zanzibar), Uganda, Zambia and Zimbabwe. The PRISMA guidelines were followed whilst conducting the review [18] (Additional file 1). The search protocol can be found in Additional file 2 .

The international bibliographic databases PubMed (http://www.ncbi.nlm.nih.gov/pubmed) and Web of Science (http://ipscience.thomsonreuters.com/product/webof-science/) were searched using the following search phrase: (cysticerc* OR cisticerc* OR "C. bovis" OR taenia* OR tenia* OR saginata OR taeniosis OR teniosis OR taeniasis OR ténia OR taeniid OR cysticerque) AND (Angola OR Botswana OR Burundi OR Comoros OR Djibouti OR Eritrea OR Ethiopia OR Kenya OR Lesotho OR Madagascar OR Malawi OR Mauritius OR Mayotte OR Mozambique OR Namibia OR Réunion OR Rwanda OR Seychelles OR Socotra OR Somalia OR South Africa OR Swaziland OR Tanzania OR Uganda OR Zanzibar OR Zambia OR Zimbabwe OR "East Africa" OR "Horn of Africa" OR "Southern Africa" OR Puntland OR Somaliland).

Furthermore, a range of databases for grey literature and $\mathrm{MSc} / \mathrm{PhD}$ thesis documents were searched using keywords from the above search phrase (the full list of databases is presented in Additional file 3). Data on bovine cysticercosis from the different scientific databases were complemented with data from OIE 
databases "Handistatius" (1996-2004) and "WAHIS" $(2005)[19,20]$. Finally, reference lists of reviews on the topic were screened and additional relevant records were added to the database.

\section{Selection criteria}

Upon compilation of search results from the different databases, duplicate records were removed. Thereafter, titles and abstracts were screened for relevance, applying the following exclusion criteria: (i) studies concerning a parasite other than T. saginata; (ii) studies conducted outside the study area; (iii) studies published outside the study period; (iv) studies reporting results outside the scope of the review question (e.g. review, experiment, intervention trial); and (v) duplicated data. After the screening process, full text articles were evaluated using the same criteria listed above (Additional file 4).

\section{Data extraction and generation}

Data from included records were extracted. In reports where the numerator and denominator of the study sample were available, prevalence data were calculated, if not already provided. When not presented in the manuscript, the 95\% exact confidence intervals (CI) were calculated, using the "binom.test" function ("stats" package) in R 3.5.1 [21].

\section{Results}

\section{Search results}

A total of 1228 records were obtained from the database search, and four additional records were added through screening of the reference lists of relevant reviews (Additional file 4). After removal of duplicate records $(n=71), 1161$ records were screened based on title and, thereafter, abstract. During title screening, 987 records were excluded, and a further 85 records were removed upon abstract screening; three of these were remaining duplicate records, whereas the other removed records focussed on a different parasite $(n=32)$ or study area $(n=18)$, were published outside the study period $(n=1)$, or had a different scope (e.g. laboratory experiments, review) $(n=31)$. Thus, 89 full text articles $(n=89)$ fulfilled the eligibility criteria for evaluation, but three of these were unavailable. During the evaluation of the remaining 86 records, eight were excluded due to having a different scope.

Thus, 78 records were included in the qualitative synthesis (journal articles: 73, online data repositories: 2 , MSc thesis: 2, PhD thesis: 1). Apart from the two OIE sources describing the occurrence of bovine cysticercosis throughout the study area, the majority of records presented data from Ethiopia $(n=37)$. The others included data from Kenya $(n=11)$, Tanzania $(n=7)$, South Africa $(n=7)$, Zambia $(n=4)$, Zimbabwe $(n=2)$, Angola $(n=2)$, Uganda $(n=1)$, Swaziland $(n=1)$, Namibia $(n=1)$, Malawi $(n=1)$, Madagascar $(n=1)$ or Botswana $(n=1)$.

\section{Human taeniosis occurrence}

A total of 48 records reported the presence of human taeniosis cases (excluding those with confirmed T. solium taeniosis). Unspecified taeniosis cases were reported from Angola, Ethiopia, Kenya, Madagascar, Malawi, South Africa, Tanzania, Uganda and Zambia, whereas known $T$. saginata taeniosis cases were reported from Ethiopia, Kenya, South Africa, Tanzania, Zambia and Zimbabwe (Fig. 1). Microscopy results were included in 32 reports, most of which presented data from Ethiopia (18) (Table 1). Taeniosis

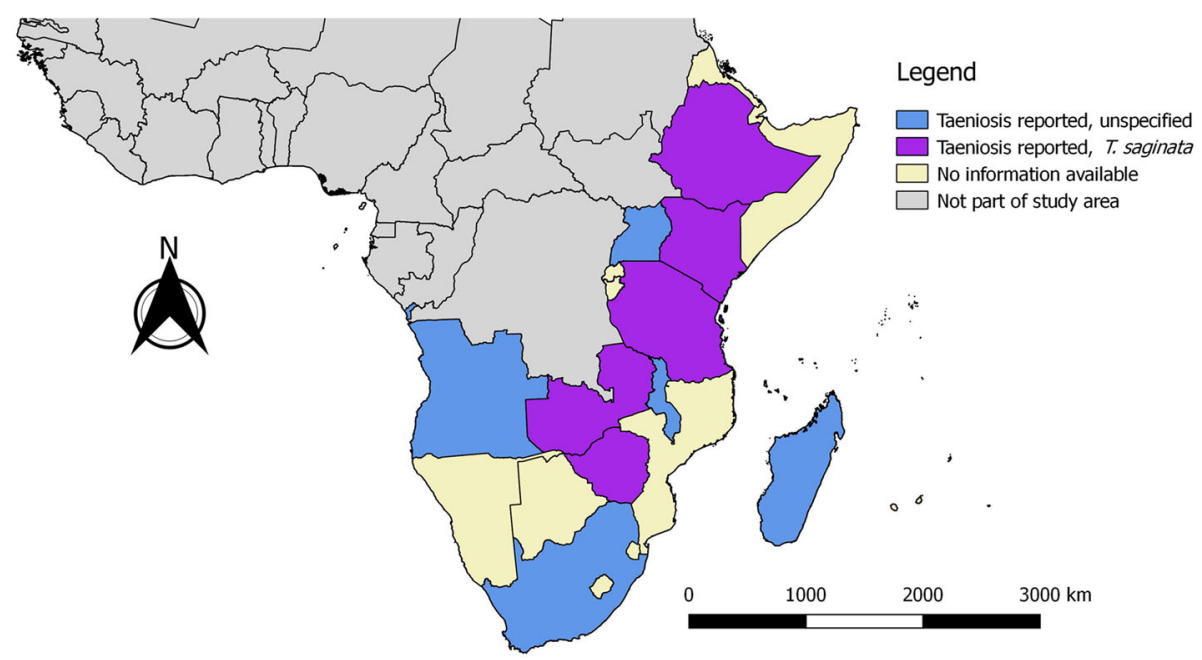

Fig. 1 Human taeniosis in southern and eastern Africa 
Table 1 Reported occurrence of taeniosis in southern and eastern Africa: microscopy studies

\begin{tabular}{|c|c|c|c|c|c|c|c|}
\hline Country & Period & $\begin{array}{l}\text { People } \\
\text { tested }\end{array}$ & $\begin{array}{l}\text { People } \\
\text { positive }\end{array}$ & $\begin{array}{l}\text { Prevalence (\%) } \\
(95 \% \mathrm{Cl})\end{array}$ & $\begin{array}{l}\text { Species } \\
\text { identification }\end{array}$ & Group studied & Reference \\
\hline Angola & $9 / 2012-12 / 2013$ & 344 & 2 & $0.58(0.07-2.1)$ & $\mathrm{N}$ & Children below 5 with diarrhea & [50] \\
\hline Angola & $1 / 2015-5 / 2015$ & 230 & 2 & $0.87(0.10-3.1)$ & N & School children in 16 schools & [51] \\
\hline Ethiopia & 11/1995-4/1996; 6-9/1996 & 1750 & 79 & $4.5(3.6-5.6)$ & $Y^{a}$ & Sugar-estate residents & [52] \\
\hline Ethiopia & $3-4 / 1999 ; 2 / 2002$ & 3167 & na & $<4$ (na) & N & $\begin{array}{l}\text { Schoolchildren, peasants and } \\
\text { teachers }\end{array}$ & [53] \\
\hline Ethiopia & $1 / 2002-2 / 2002$ & 104 & 1 & $0.96(0.02-5.2)$ & $Y^{a}$ & $\begin{array}{l}\text { HIV/AIDS and HIV-seronegative } \\
\text { individuals in a teaching hospital }\end{array}$ & [54] \\
\hline Ethiopia & 2007-2012 & 32191 & 322 & $1.0(0.9-1.1)$ & N & Rural hospital visiters & [55] \\
\hline Ethiopia & $5 / 2007-6 / 2007$ & 419 & na & 1.4 (na) & N & na & [56] \\
\hline Ethiopia & $12 / 2007-2 / 2008$ & 7171 & 23 & $0.32(0.20-0.48)$ & N & Visitors of health centers & [57] \\
\hline Ethiopia & $8 / 2008-12 / 2008$ & 343 & 14 & $4.1(2.2-6.8)$ & N & HIV patients recruited at hospital & [58] \\
\hline Ethiopia & $11 / 2008$ & 121 & 5 & $4.1(1.4-9.4)$ & N & Prison inmates & [59] \\
\hline Ethiopia & $11 / 2008$ & 115 & 1 & $0.87(0.02-4.7)$ & N & Tobacco farm workers & [59] \\
\hline Ethiopia & $4 / 2009$ & 384 & 5 & $1.3(0.4-3.0)$ & N & Food handlers & [60] \\
\hline Ethiopia & 9/2010-7/2011 & 858 & 18 & $2.1(1.2-3.3)$ & N & Highland and lowland dwellers & [61] \\
\hline Ethiopia & $1 / 2011-6 / 2011$ & 200 & 1 & $0.5(0.01-2.8)$ & N & Food handlers & [62] \\
\hline Ethiopia & $3 / 2012-11 / 2012$ & 260 & 1 & $0.38(0.01-2.12)$ & N & Children recruited in Health Center & [63] \\
\hline Ethiopia & $1 / 2013-5 / 2013$ & 172 & 5 & $2.9(1.0-6.7)$ & N & Asymptomatic food handlers & [64] \\
\hline Ethiopia & $8 / 2013-11 / 2013$ & 180 & 2 & $1.1(0.13-4.0)$ & N & $\begin{array}{l}\text { HAART initiated and naive paediatric } \\
\text { HIV patients }\end{array}$ & [65] \\
\hline Ethiopia & $1 / 2015-2 / 2015$ & 503 & 13 & $2.6(1.4-4.4)$ & N & School children from 5 schools & [66] \\
\hline Ethiopia & 1/2016-8/2016 & 213 & 5 & $2.3(0.8-5.4)$ & N & Active pulmonary TB patients & [67] \\
\hline Ethiopia & na & 1537 & na & 8.1 (na) & $Y^{a}$ & $\begin{array}{l}\text { Participants from } 19 \text { communities, } \\
\text { includes children and adults }\end{array}$ & [23] \\
\hline Ethiopia & na & 491 & 12 & $2.4(1.3-4.2)$ & N & Villagers & [68] \\
\hline Kenya & 2000-2009 & 31 & 1 & $3.2(0.08-16.7)$ & N & Sleeping sickness patients & [69] \\
\hline Kenya & $7 / 2010-7 / 2012$ & 2057 & na & $0.20(n a)$ & N & na & [22] \\
\hline Kenya & 8/2010-7/2012 & 2113 & na & $0.30(0-0.5)$ & N & Mixed-farming community & [26] \\
\hline Kenya & na & 285 & na & 5.3 (na) & N & HIV-positive patients & [70] \\
\hline Kenya & na & 151 & 0 & $0(0-2.4)$ & $\mathrm{N}$ & Geophagous pregnant women & [24] \\
\hline Madagascar & 11/1996-1/1997 & 401 & 3 & $0.75(0.15-2.2)$ & N & $\begin{array}{l}\text { Patients referred for parasitological } \\
\text { examination }\end{array}$ & [71] \\
\hline South Africa & 2009 & na & 2 & na & $\mathrm{N}$ & Laboratory results & [72] \\
\hline South Africa & 2009 & na & 4 & na & Y & Laboratory results & [72] \\
\hline South Africa & 4/2009-9/2009 & 162 & 3 & $1.9(0.4-5.3)$ & N & School children & [73] \\
\hline South Africa & 2010 & na & 11 & na & Y & Laboratory results & [72] \\
\hline South Africa & 2010 & na & 1 & na & N & Laboratory results & [72] \\
\hline South Africa & na & 183 & 3 & $1.6(0.3-4.7)$ & N & Rural black preschool children & [74] \\
\hline Tanzania & 2008-2009 & 1057 & 3 & $0.30(0.06-0.8)$ & $Y^{b}$ & $\begin{array}{l}\text { Villagers, after treatment with } \\
\text { niclosamide/praziquantel and } \\
\text { purgation }\end{array}$ & [75] \\
\hline Uganda & na & 5313 & 36 & $0.70(0.5-0.9)$ & N & Primary school children & [76] \\
\hline Zambia & 6/2007-8/2007 & 403 & na & 0.90 (na) & $\mathrm{N}$ & School children & [77] \\
\hline
\end{tabular}

${ }^{a}$ Reported as $T$. saginata, yet unclear from methodology 
Table 2 Reported occurrence of taeniosis in southern and eastern Africa: coproAg-ELISA studies

\begin{tabular}{llllllll}
\hline Country & Study period & People tested & People positive & $\begin{array}{l}\text { Prevalence (\%) } \\
95 \% \mathrm{Cl}\end{array}$ & Species identification & Group studied \\
\hline Kenya & $1 / 2007-4 / 2007$ & 204 & 12 & $5.9(3.1-10.0)$ & $Y^{\mathrm{a}}$ & Deference \\
Kenya & $8 / 2010-7 / 2012$ & 2113 & na & $19.7(16.7-22.7)$ & $\mathrm{N}$ & Mixed-farming community inhabitants & [26] \\
Kenya & na & 691 & na & $1.9(\mathrm{na})$ & $\mathrm{N}$ & Slaughterhouse workers & {$[79]$} \\
Zambia & 2006 & 190 & 5 & $2.6(0.9-6.0)$ & $Y^{\mathrm{a}}$ & Pupils primary schools & [78] \\
Zambia & $8 / 2009 ; 10 / 2010$ & 817 & 1 & $0.12(0.003-0.68)$ & $Y^{b}$ & Consenting villagers & [25] \\
\hline
\end{tabular}

${ }^{a}$ Results based on coproAg-ELISA, specific for T. saginata

${ }^{\mathrm{b}}$ Results based on coproAg-ELISA with coproPCR ( $T$. saginata specific) confirmation

Abbreviations: $\mathrm{Cl}$, confidence interval; na, not available

prevalence based on microscopy alone ranged between $0.2-8.1 \%$ (villagers in Kenya [22] and Ethiopia [23], respectively), and one study reported the absence of taeniosis (in geophagous pregnant women in Kenya [24]). Four records presented data from coproAg-ELISA studies conducted in Kenya and/or Zambia, with a prevalence ranging between 0.12$19.7 \%$ (villagers in Zambia [25] and Kenya [26], respectively) (Table 2), two of which involved confirmed $T$. saginata cases. Overall, common study groups were school-children, patients suffering from other diseases [e.g. HIV infection, sleeping sickness and active pulmonary tuberculosis (TB)], as well as occupational groups (e.g. tobacco farm workers, food handlers). Furthermore, eight studies reported taeniosis prevalence in communities based on selfreporting by questionnaire respondents (prevalence range: $45.5-64.2 \%$ ) (Table 3 ), and five records presented data on anthelmintic sales in towns (Table 4), both in Ethiopia. Another two records contained data on household latrine sampling, thus presenting prevalence at the household level (Malawi: 40.4\% [27]; South Africa: $18.0 \%$ [28]). Finally, one report discussed a case of intestinal obstruction due to impaction of a $T$. saginata tapeworm in Zimbabwe, requiring enterotomy with bolus removal as well as appendectomy [29].

\section{Bovine cysticercosis}

Based on the retrieved data sources (both OIE databases and manuscripts/reports), the presence of bovine cysticercosis was reported in all of the 27 countries/territories studied, except for Comoros, Madagascar, Mauritius, Mayotte and Seychelles. In addition, no information was available for Rwanda, Somalia, Mayotte and Socotra (Fig. 2). Data from the two OIE data sources indicating the occurrence and/or number of cases are presented in Table 5. Apart from the OIE data sources, a total of 39 records were found to document results on bovine cysticercosis in the study region. Meat inspection results were included in 35 records (Table 6), with prevalence estimates ranging between $0.02-26.3 \%$, while two records reported the absence of positive animals (Tanzania: 2011 [30], Zambia: 2001 [31]). Seven records provided serological data, mostly based on Ag-ELISA results (prevalence range: 6.1-53.5\%), while one presented Ab-ELISA data (prevalence: 10.0\%) [32] and another IHAT results (prevalence: 25.7\%) [33] (Table 7). One study estimated the town level costs due to condemnation caused by bovine cysticercosis [Mekelle, abattoir level: 31,952 ETB/6 months (991 EUR, according to July 2018 exchange rates; 1 ETB $=0.0310$ EUR) [34]], and another five studies provided data on total economic losses due to condemnation for a wide variety of conditions [17, 30, 35-37]. Overall, the

Table 3 Reported occurrence of taeniosis: questionnaire studies in Ethiopia

\begin{tabular}{|c|c|c|c|c|c|}
\hline Town & Study period & People interviewed & $\begin{array}{l}\text { People reporting } \\
\text { infection }\end{array}$ & $\begin{array}{l}\text { Prevalence (\%) } \\
95 \% \mathrm{Cl}\end{array}$ & $\overline{\text { Reference }}$ \\
\hline Awassa & $10 / 2005-4 / 2006$ & 120 & 77 & $64.2(54.9-72.7)$ & [44] \\
\hline Soddo & $11 / 2007-4 / 2008$ & 79 & 40 & $50.6(39.1-62.1)$ & {$[45]$} \\
\hline Jimma & $11 / 2008-3 / 2009$ & 60 & 34 & $56.7(43.2-69.4)$ & [46] \\
\hline Yirgalem & $11 / 2009-3 / 2011$ & 170 & 119 & $70.0(62.5-76.8)$ & [47] \\
\hline Sebeta, Tulu Bolo, Weliso & na & 392 & na & 55.1 (na) & {$[48]$} \\
\hline Harar & na & 300 & 182 & $60.7(54.9-66.2)$ & [16] \\
\hline Adama & $11 / 2013-4 / 2014$ & 200 & 91 & $45.5(38.5-52.7)$ & {$[15]$} \\
\hline Batu & $12 / 2014-4 / 2015$ & 100 & 59 & $59.0(48.7-68.7)$ & [49] \\
\hline
\end{tabular}

Abbreviations: $\mathrm{Cl}$, confidence interval; na, not available 
Table 4 Reported town level taeniicidal sales in Ethiopia

\begin{tabular}{|c|c|c|c|c|c|}
\hline Town & Year & Number & Value (ETB) & Value (EUR) ${ }^{a}$ & Reference \\
\hline Awassa & 2002 & $1,582,254$ & $1,880,330$ & 58,290 & [44] \\
\hline Awassa & 2003 & $1,221,004$ & $1,746,585$ & 54,144 & [44] \\
\hline Awassa & 2004 & 946,330 & $1,803,300$ & 55,902 & [44] \\
\hline Awassa & 2005 & 889,759 & $1,788,776$ & 55,452 & [44] \\
\hline Soddo & 2004 & 74,747 & 192,979 & 5982 & [45] \\
\hline Soddo & 2005 & 77,705 & 203,675 & 6342 & [45] \\
\hline Soddo & 2006 & 79,230 & 210,133 & 6314 & [45] \\
\hline Soddo & 2007 & 105,090 & 279,660 & 8669 & [45] \\
\hline Jimma & 2007 & 51,462 & na & na & [46] \\
\hline Jimma & 2008 & 52,134 & na & na & [46] \\
\hline Yirgalem & 2005 & 95,712 & na & na & [47] \\
\hline Yirgalem & 2006 & 93,059 & na & na & {$[47]$} \\
\hline Yirgalem & 2007 & 95,093 & na & na & [47] \\
\hline Yirgalem & 2008 & 95,121 & na & na & {$[47]$} \\
\hline Yirgalem & 2009 & 93,028 & na & na & {$[47]$} \\
\hline Batu & 2013 & 42,557 & 148,100 & 4591 & [49] \\
\hline Batu & 2014 & 29,049 & 97,492 & 3022 & [49] \\
\hline
\end{tabular}

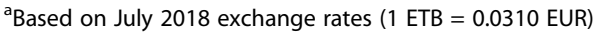
Abbreviation: na, not available

majority of records presented data from Ethiopia (21/ $41)$, followed by Tanzania (8/41) and Kenya (7/41).

\section{Taeniosis and bovine cysticercosis occurrence}

The co-occurrence of both bovine cysticercosis and taeniosis during the study period was reported in Angola, Ethiopia, Malawi, South Africa, Tanzania, Uganda, Zambia and Zimbabwe, but this was not the case for the other countries/territories studied. The occurrence of bovine cysticercosis or taeniosis was reported for all the countries/territories studied, except for Somalia, Rwanda and the Comoros, Mauritius, Mayotte, Seychelles, Mayotte and Socotra islands.

\section{Discussion}

The present study aimed at describing the epidemiology of $T$. saginata taeniosis/cysticercosis in eastern and southern Africa (1990-2017). Based on our findings, both human taeniosis and bovine cysticercosis were widespread in the 27 countries/territories studied, except for Somalia, Rwanda and six island states/territories, indicating that $T$. saginata is present in most countries of the study area. However, lack of diagnosis and reporting, particularly in rural areas, mean that the data accrued are likely to underestimate occurrence. The absence of data for some countries does not exclude the possibility that this parasite is present there as well. For example, given that of the three countries bordering Rwanda that are included in this review (Burundi, Tanzania and Uganda) all report the presence of this parasite, it seems unlikely that Rwanda is free from $T$. saginata. On the other hand, one potential hypothesis for the lack of reported T. saginata in Rwanda is the remarkably higher rate of access to improved sanitation services, at $60.8 \%$ in comparison to neighbouring Burundi at 35.5\% [38]. The Rwandan civil war, during 1990-1994, culminating in the genocide of 1994, may have impacted reporting during that period, but does not explain the more recent lack of reporting. For Somalia, the ongoing civil war might explain the lack of reported data for the country, whereas for the six island states and territories, governmental or scientific interest in reporting cases may be lacking.

Cases of taeniosis were reported for Angola, Ethiopia, Kenya, Madagascar, Malawi, South Africa, Tanzania,

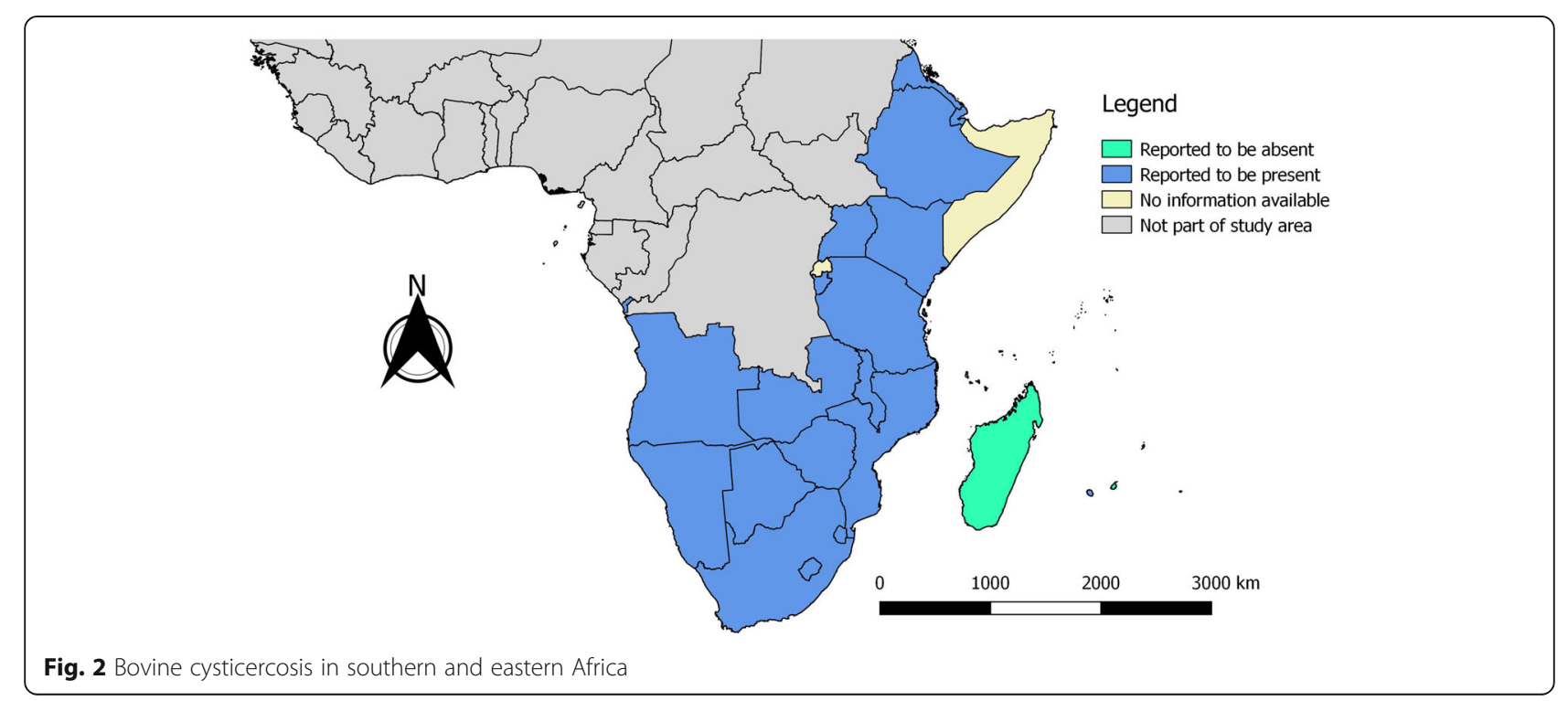


Table 5 OlE data on occurrence of bovine cysticercosis in the southern and eastern Africa $(1996-2005)[19,20]$

\begin{tabular}{|c|c|c|c|c|c|c|c|c|c|c|}
\hline \multirow[t]{2}{*}{ Country } & \multicolumn{10}{|l|}{ Year } \\
\hline & 1996 & 1997 & 1998 & 1999 & 2000 & 2001 & 2002 & 2003 & 2004 & 2005 \\
\hline Angola & 6 & 11 & na & na & na & na & na & na & 4 & + \\
\hline Botswana & na & 53 & 4356 & 12,863 & 14,000 & 14,000 & 10,181 & 15,363 & na & + \\
\hline Burundi & na & na & na & na & na & + & na & na & na & na \\
\hline Comoros & na & na & - & na & na & na & na & na & na & na \\
\hline Djibouti & na & na & na & na & na & na & + & + & + & + \\
\hline Eritrea & + & + & + & 2 & + & + & na & + & 370 & - \\
\hline Ethiopia & + & na & na & na & na & + & + & + & + & + \\
\hline Kenya & + & + & + & + & + & + & + & + & 3999 & na \\
\hline Lesotho & 56 & 38 & 139 & na & na & na & 68 & na & na & - \\
\hline Madagascar & na & na & na & na & na & na & - & na & na & - \\
\hline Malawi & + & + & + & + & + & + & + & + & 6 & + \\
\hline Mauritius & na & na & na & na & na & - & - & - & - & na \\
\hline Mozambique & + & + & + & na & na & na & na & na & na & - \\
\hline Namibia & + & 3833 & 3118 & + & 2852 & 2226 & 2399 & 54 & 1616 & + \\
\hline Réunion & + & na & na & - & - & - & - & - & na & - \\
\hline Rwanda & na & na & na & na & na & na & na & na & na & na \\
\hline Seychelles & - & - & - & na & - & na & - & na & - & na \\
\hline Somalia & na & na & na & na & na & na & na & na & na & na \\
\hline South Africa & + & + & + & + & + & + & + & + & + & + \\
\hline Swaziland & 969 & + & + & + & 1419 & 530 & 245 & 1909 & 561 & + \\
\hline Tanzania & + & + & + & + & na & na & + & 6 & na & + \\
\hline Uganda & + & 24 & 152 & + & + & + & + & na & na & + \\
\hline Zambia & na & na & na & na & + & na & 2 & 248 & na & na \\
\hline Zimbabwe & 244 & 1744 & 2062 & 1988 & 160 & 1447 & + & na & na & na \\
\hline
\end{tabular}

Abbreviations: na, not available; + , occurrence of the disease; -, absence of the disease

Uganda, Zambia and Zimbabwe, yet the majority of reports on human taeniosis cases did not, unfortunately, provide species determination. Thus, cases of $T$. saginata taeniosis were not differentiated from infections caused by other Taenia spp. The pork tapeworm, $T$. solium, for instance, is presumed to also be widely distributed throughout eastern and southern Africa [39] and therefore we cannot conclude that all reported, unspecified taeniosis cases are due to T. saginata. Taenia solium is known to be the causative agent of the severe condition neurocysticercosis, associated with epilepsy, severe headaches, cognitive deficits [40] and a major cause of deaths among the food-borne diseases [41]. The presence of a single T. solium tapeworm carrier poses a major risk for his/her surroundings, as humans acquire neurocysticercosis through the ingestion of $T$. solium eggs transmitted through poor hygiene practices resulting in faecal-oral transmission [42]. Although tapeworm infections usually have an asymptomatic course [7] apart from some sporadic complications (e.g. intestinal obstruction in the Zimbabwean patient [29]), it is thus paramount to register cases as well as to differentiate case species, to allow precise prevalence estimates, and to guide appropriate control measures. Species determination, however, is hampered by the fact that Taenia spp. eggs cannot be differentiated upon coprological examination. Expelled proglottids of $T$. solium and $T$. saginata can be distinguished on the basis of the number of uterine branches, but such material is not always available. Moreover, more advanced diagnostic tools (e.g. copro-PCR) to differentiate species are often lacking in resource poor settings [43], and even in developed countries are not often performed due to lack of awareness about neurocysticercosis [12].

In certain countries in the study area, specific culinary habits put the consumers at great risk of contracting $T$. saginata taeniosis. For instance, in Ethiopia, "kitfo" is a very popular beef dish, in which the meat is usually consumed raw or lightly cooked, while "tibs" is another dish often containing undercooked beef. Furthermore, "kurt" 
Table 6 Reported occurrence of bovine cysticercosis in southern and eastern Africa: meat inspection studies

\begin{tabular}{|c|c|c|c|c|c|}
\hline Country & Period & Animals tested & Animals positive & $\begin{array}{l}\text { Prevalence (\%) } \\
(95 \% \mathrm{Cl})\end{array}$ & Reference \\
\hline Botswana & 1995 & na & na & na $(9.1-12.6)$ & {$[80]$} \\
\hline Ethiopia & 9/2004-8/2005 & 11,227 & 842 & $7.5(7.0-8.0)$ & {$[81]$} \\
\hline Ethiopia & $9 / 2005-2 / 2007$ & 4456 & 824 & $18.5(17.4-19.7)$ & {$[82]$} \\
\hline Ethiopia & $10 / 2005-4 / 2006$ & 400 & 105 & $26.3(22.0-30.9)$ & {$[83]$} \\
\hline Ethiopia & $12 / 2006-7 / 2007$ & 3711 & 308 & $8.3(7.4-9.2)$ & [34] \\
\hline Ethiopia & 10/2007-3/2008 & 512 & 15 & $2.9(1.6-4.8)$ & {$[84]$} \\
\hline Ethiopia & $11 / 2007-4 / 2008$ & 415 & 47 & $11.3(8.4-14.8)$ & {$[45]$} \\
\hline Ethiopia & $12 / 2007-2 / 2008$ & 1023 & 74 & $7.2(5.7-9.0)$ & [57] \\
\hline Ethiopia & $11 / 2008-3 / 2009$ & 500 & 22 & $4.4(2.8-6.6)$ & {$[46]$} \\
\hline Ethiopia & 10/2009-9/2010 & 898 & 177 & $19.7(17.2-22.5)$ & {$[16]$} \\
\hline Ethiopia & $11 / 2009-3 / 2011$ & 400 & 48 & $12(9.0-15.6)$ & {$[47]$} \\
\hline Ethiopia & 2010 & 12,708 & 669 & $5.3(4.9-5.7)$ & {$[37]$} \\
\hline Ethiopia & 9/2010-9/2012 & 3055 & 126 organs & na & [35] \\
\hline Ethiopia & 2011 & 34,674 & 3259 & $9.4(9.1-9.7)$ & {$[37]$} \\
\hline Ethiopia & 2012 & 10,363 & 803 & $7.7(7.2-8.3)$ & {$[37]$} \\
\hline Ethiopia & $10 / 2012-4 / 2013$ & 745 & 21 organs & na & {$[35]$} \\
\hline Ethiopia & 2013 & 5172 & 247 & $4.8(4.2-5.4)$ & {$[37]$} \\
\hline Ethiopia & $11 / 2013-4 / 2014$ & 384 & 10 & $2.6(1.3-4.7)$ & {$[15]$} \\
\hline Ethiopia & $11 / 2013-5 / 2014$ & 3675 & 40 organs & na & {$[36]$} \\
\hline Ethiopia & 05/2014-6/2014 & 439 & 23 & $5.2(3.3-7.8)$ & {$[85]$} \\
\hline Ethiopia & $12 / 2014-4 / 2015$ & 384 & 10 & $2.6(1.3-4.7)$ & [49] \\
\hline Ethiopia & na & 522 & 39 & $7.4(5.4-10.1)$ & [33] \\
\hline Ethiopia & na & 1022 & 64 & $6.3(4.9-7.9)$ & {$[17]$} \\
\hline Ethiopia & na & 1216 & na & 4.6 (na) & {$[48]$} \\
\hline Kenya & 1974 & 77,810 & 6784 & $8.8(8.5-8.9)$ & {$[86]$} \\
\hline Kenya & 1975-1978 & na & na & $<6.0$ (na) & {$[86]$} \\
\hline Kenya & 1979-1983 & na & na & $<4.0$ (na) & {$[86]$} \\
\hline Kenya & 1984 & na & na & $1.8(\mathrm{na})$ & {$[86]$} \\
\hline Kenya & 1985-1990 & na & na & $<2.0$ (na) & {$[86]$} \\
\hline Kenya & 1991 & 315,801 & 3457 & $1.1(1.06-1.13)$ & {$[86]$} \\
\hline Kenya & 9/2006-1/2007 & 188 & 6 & $3.2(1.2-6.8)$ & {$[87]$} \\
\hline Kenya & na & 511 & 39 & $7.6(5.5-10.3)$ & {$[88]$} \\
\hline Kenya & na & 1184 & 189 & $16.0(13.9-18.2)$ & [32] \\
\hline Namibia & 2000 & 12,204 & 973 & $8.0(7.5-8.5)$ & [89] \\
\hline Namibia & 2001 & 7888 & 713 & $9.0(8.4-9.7)$ & {$[89]$} \\
\hline Namibia & 2002 & 10,561 & 798 & $7.6(7.1-8.1)$ & [89] \\
\hline Namibia & 2003 & 4411 & 347 & $7.9(7.1-8.7)$ & [89] \\
\hline Namibia & 2004 & 5309 & 401 & $7.6(6.9-8.3)$ & [89] \\
\hline Namibia & 2006 & 7085 & 435 & $6.1(5.6-6.7)$ & {$[89]$} \\
\hline Namibia & 2006 & 71,388 & 243 & $0.34(0.30-0.39)$ & [89] \\
\hline South Africa & 2009-2011 & $1,022,556$ & 24,443 & $2.39(2.36-2.42)$ & [90] \\
\hline South Africa & 2010 & 356,006 & 2169 & $0.61(0.58-0.64)$ & [91] \\
\hline South Africa & 2011 & 349,458 & 2389 & $0.68(0.66-071)$ & [91] \\
\hline
\end{tabular}


Table 6 Reported occurrence of bovine cysticercosis in southern and eastern Africa: meat inspection studies (Continued)

\begin{tabular}{|c|c|c|c|c|c|}
\hline Country & Period & Animals tested & Animals positive & $\begin{array}{l}\text { Prevalence (\%) } \\
(95 \% \mathrm{Cl})\end{array}$ & Reference \\
\hline South Africa & 2012 & 348,309 & 1980 & $0.57(0.54-0.59)$ & [91] \\
\hline South Africa & 2013 & 361,232 & 3382 & $0.94(0.91-0.97)$ & [91] \\
\hline Tanzania & 1987-1989 & 42,434 & na & 16.4 (na) & [92] \\
\hline Tanzania & $1 / 2002-4 / 2004$ & 12,444 & 185 & $1.5(1.3-1.7)$ & [93] \\
\hline Tanzania & 2005 & na & 19 & 0.06 (na) & [94] \\
\hline Tanzania & 2006 & na & 24 & 0.06 (na) & [94] \\
\hline Tanzania & 2007 & na & 16 & 0.04 (na) & [94] \\
\hline Tanzania & 2010 & 27,444 & 20 organs & na & {$[30]$} \\
\hline Tanzania & 2/2010-1/2011 & 30,713 & 18 organs & na & [95] \\
\hline Tanzania & 2011 & 30,671 & 0 organs & na & {$[30]$} \\
\hline Tanzania & 2012 & 27,865 & 6 organs & na & {$[30]$} \\
\hline Tanzania & $12 / 2013$ & 2438 & 1 and $0.1 \%$ organs & na & {$[30]$} \\
\hline Tanzania & na & na & 21 & na & {$[96]$} \\
\hline Zambia & 2000 & 4629 & 1 & $0.02(0.0005-0.12)$ & {$[31]$} \\
\hline Zambia & 2001 & 9422 & 0 & $0(0-0.04)$ & {$[31]$} \\
\hline Zambia & 2002 & 10,147 & 2 & $0.02(0.002-0.07)$ & {$[31]$} \\
\hline Zambia & 2003 & 11,519 & 2 & $0.02(0.002-0.06)$ & [31] \\
\hline Zimbabwe & 1/2006-12/2007 & 86,080 & 1364 & $1.6(1.5-1.7)$ & [97] \\
\hline
\end{tabular}

Abbreviations: $\mathrm{Cl}$, confidence interval; na, not available

refers to the habit of eating cubes of raw beef, finished off with local spices. Unsurprisingly, a high proportion of the Ethiopian population reports having had a tapeworm, and sales of taeniicidal drugs in Ethiopia are high $[15,16,44-49]$.

Access to adequate clean water and sanitation services (WASH) is notoriously poor across the whole of sub-Saharan Africa, including the region of interest to this paper. There are large between and within-country disparities, but overall sub-Saharan Africa lags far behind the goals set out by the international community in both the millennium development and the sustainable development goals with only $25.7 \%(23.1-28.6 \%)$ of the population having access to improved sanitation [38]. This lack of WASH capacity is strongly reflected by the presence of parasites such as $T$. saginata which requires ingestion of eggs passed in faecal material for the propagation of its life-cycle.

In eastern and southern Africa the cattle population is large, and bovine products, including meat, are an

Table 7 Reported occurrence of bovine cysticercosis in southern and eastern Africa: serological studies

\begin{tabular}{|c|c|c|c|c|c|c|}
\hline Country & Period & Diagnostic tool & Animals tested & Animals positive & $\begin{array}{l}\text { Prevalence (\%) } \\
95 \% \mathrm{Cl}\end{array}$ & Reference \\
\hline Ethiopia & na & IHAT & 743 & 190 & $25.6(22.4-28.9)$ & [33] \\
\hline Kenya & 9/2006-1/2007 & Ag-ELISA & 188 & 44 & $23.4(17.8-30.1)$ & {$[87]$} \\
\hline Kenya & 10/2006-11/2006 & Ag-ELISA & 792 & 143 & $18.1(15.4-20.9)$ & {$[87]$} \\
\hline Kenya & 8/2010-7/2012 & Ag-ELISA & 983 & na & $53.5(48.7-58.3)$ & {$[26]$} \\
\hline Kenya & na & Ag-ELISA & 511 & 117 & $22.9(19.3-26.8)$ & {$[88]$} \\
\hline Kenya & na & Ag-ELISA & 1184 & 413 & $34.9(32.2-37.7)$ & [32] \\
\hline Kenya & na & Ab-ELISA & 1184 & 118 & $10.0(8.3-11.8)$ & [32] \\
\hline South Africa & na & Ag-ELISA & 1315 & 300 & $22.8(20.6-25.2)$ & {$[98]$} \\
\hline South Africa & na & $\mathrm{Ag}$-ELISA & 1159 & 174 & $15.0(13.0-17.2)$ & [98] \\
\hline Swaziland & na & Ag-ELISA & 600 & na & 28.0 (na) & [99] \\
\hline Zambia & 12/1999-9/2000 & Ag-ELISA & 628 & 38 & $6.1(4.3-8.2)$ & {$[100]$} \\
\hline
\end{tabular}


important protein source for humans, as well as a source of draft power and form of investment. Beef cattle are typically kept in an extensive manner; animals are basically free-ranging. The presence of human $T$. saginata carriers shedding eggs into the environment puts these cattle at risk of bovine cysticercosis, and this presumably occurs widely in the study area. In developed countries, the condition is known to cause economic losses due to freezing or condemnation of the carcass as well as related insurance costs (e.g. Belgium: 3,408,455 EUR/year [13]). Studies investigating the magnitude of this economic loss in the study area are, however, limited, with data available from only one abattoir in Ethiopia [34]. Furthermore, reporting of bovine cysticercosis to OIE appeared to be inconsistent, with large variations in number of cases reported even within the same country, and gaps in the annual reporting (e.g. no data available after 2005).

\section{Conclusions}

Taenia saginata taeniosis/cysticercosis is a widespread, yet largely ignored, condition in southern and eastern Africa. This is probably due to the lack of symptoms in cattle, the lack of good data on its economic impact, and because human taeniosis is considered a minor health problem. Nevertheless, the presence of bovine cysticercosis is a clear sign of inadequate sanitation, insufficient meat inspection, and culinary habits that may favour transmission. Measures to reduce transmission of $T$. saginata are therefore warranted, and the infection should be properly monitored, in both humans and cattle. It should also be noted that as cattle are an important source of human protein and livelihoods in the area, ensuring optimal health and productivity of cattle is of indirect importance to human health and welfare as well as any direct impact. Species identification in tapeworm carriers is paramount to gain detailed insights in the distribution of the different Taenia spp. in the area, as well to avoid the development of the severe condition neurocysticercosis within communities due to ingestion of eggs shed by a T. solium tapeworm carrier. We conclude that in order to ensure both the safety of beef consumed in the southern and eastern Africa, and to improve the underlying sanitary conditions perpetuating the parasitic life-cycle, concerted, co-ordinated efforts must be made by integrating public, animal and environmental health in a One Health approach.

\section{Additional files}

Additional file 1: PRISMA checklist. (DOC $63 \mathrm{~kb}$ )

Additional file 2: Search protocol of systematic review. (DOCX $18 \mathrm{~kb}$ )

Additional file 3: Databases used in systematic review. (DOCX 16 kb)
Additional file 4: PRISMA flow chart for systematic review. (TIF $1629 \mathrm{~kb}$ )

\section{Abbreviations}

ETB: Ethiopian Birr; EUR: Euro; HAART: Highly active antiretroviral therapy; IHAT: Indirect hemagglutination test; OIE: World Organisation for Animal Health/Office International des Epizooties

\section{Acknowledgments}

This work was performed within the framework of CYSTINET, the European network on taeniosis/cysticercosis, COST ACTION TD1302.

\section{Funding}

Not applicable.

Availability of data and materials

The data supporting the conclusions of this article are included within the article and its additional files.

\section{Authors' contributions}

VD conducted the systematic review of literature, extracted and analysed the data and drafted the first version of the manuscript. All authors contributed to the design of the study, interpretation of the data and writing the paper. All authors read and approved the final manuscript.

Ethics approval and consent to participate

Not applicable.

Consent for publication

Not applicable.

\section{Competing interests}

The authors declare that they have no competing interests.

\section{Publisher's Note}

Springer Nature remains neutral with regard to jurisdictional claims in published maps and institutional affiliations.

\section{Author details}

${ }^{1}$ Department of Biomedical Sciences, Institute of Tropical Medicine, Antwerp, Belgium. ${ }^{2}$ Department of Virology, Parasitology and Immunology, Faculty of Veterinary Medicine, Ghent University, Merelbeke, Belgium. ${ }^{3}$ One Health Center for Zoonoses and Tropical Veterinary Medicine, Ross University School of Veterinary Medicine, Basseterre, Saint Kitts, Trinidad and Tobago. ${ }^{4}$ Department of Epidemiology and Public Health, Sciensano, Brussels, Belgium. ${ }^{5}$ Department of Veterinary Public Health and Food Safety, Faculty of Veterinary Medicine, Ghent University, Merelbeke, Belgium. ' $P$ Parasitology, Department of Food Safety and Infection Biology, Faculty of Veterinary Medicine, Norwegian University of Life Sciences, Adamstuen Campus, Oslo, Norway. ${ }^{7}$ Laboratory of Parasitology, Veterinary Research Institute, Hellenic Agricultural Organization Demeter, Thermi, 57001 Thessaloniki, Greece. ${ }^{8}$ International Livestock Research Institute (ILRI), P.O. Box 30709, Nairobi, Kenya. ${ }^{9}$ Institute for Infection and Global Health, University of Liverpool, Neston, UK.

Received: 26 July 2018 Accepted: 22 October 2018

Published online: 06 November 2018

References

1. Del Brutto OH, García HH. Taenia solium cysticercosis - the lessons of history. J Neurol Sci. 2015;359:392-5.

2. Goeze J. Versuch einer Naturgeschichte der Eingeweidewürmer thierischer Körper. Blankenburg, Germany: Philipp Adam Pape; 1782

3. Oliver J. Seventh annual report of the sanitary commissioner (1870) of the Government of India. Calcutta, India: Government Printing House; 1871.

4. Murrell KD. Epidemiology of taeniosis and cysticercosis. In: Murrell KD, editor. WHO/FAO/OIE guidelines for the surveillance, prevention and control of taeniosis/cysticercosis. Paris: Office International des Epizooties (OIE); 2005. p. 27-43.

5. Dorny P, Praet N. Taenia saginata in Europe. Vet Parasitol. 2007;149:22-4. 
6. Scandrett B, Parker S, Forbes L, Gajadhar A, Dekumyoy P, Waikagul J, et al. Distribution of Taenia saginata cysticerci in tissues of experimentally infected cattle. Vet Parasitol. 2009;164:223-31.

7. Tembo A, Craig PS. Taenia saginata taeniosis: copro-antigen time-course in a voluntary self-infection. J Helminthol. 2015;89:612-9.

8. Craig P, Ito A. Intestinal cestodes. Curr Opin Infect Dis. 2007;20:524-32.

9. Bryce A. I have a pathological fear of tapeworms. Tonic. 2017. https://tonic. vice.com/en_us/article/wj8x5z/i-have-a-pathological-fear-of-tapeworms. Accessed 26 Apr 2018

10. Butcher $\mathrm{N}$. The strange case of the walking corpse: a chronicle of medical mysteries, curious remedies, and bizarre but true healing folklore. New York, USA: Avery; 2004.

11. Karatepe O, Adas G, Tukenmez M, Battal M, Altiok M, Karahan S. Parasitic infestation as cause of acute appendicitis. G Chir. 2009;30:426-8.

12. Laranjo-González M, Devleesschauwer B, Trevisan C, Allepuz A, Sotiraki S, Abraham A, et al. Epidemiology of taeniosis/cysticercosis in Europe, a systematic review: Western Europe. Parasit Vectors. 2017;10:349.

13. Jansen F, Dorny P, Trevisan C, Dermauw V, Laranjo-González M, Allepuz A, et al. Economic impact of bovine cysticercosis and taeniosis caused by Taenia saginata in Belgium. Parasit Vectors. 2018;11:241.

14. FAO. Food and Agriculture Organization of the United Nations Statistical Databases. 2016. http://faostat3.fao.org. Accessed 26 Apr 2018.

15. Tolossa Y, Taha A, Terefe G, Jibat T. Bovine cysticercosis and human taeniosis in Adama town, Oromia region, Ethiopia. J Vet Sci Technol. 2015;\$10:003.

16. Terefe Y, Redwan F, Zewdu E. Bovine cysticercosis and its food safety implications in Harari People's National Regional State, eastern Ethiopia. Onderstepoort J Vet Res. 2014,81:676.

17. Shiferaw S, Kumar A, Amssalu K. Organs condemnation and economic loss at Mekelle municipal abattoir. Ethiopia. Haryana Vet. 2009;48:17-22.

18. Moher D, Liberati A, Tetzlaff J, Altman DG, Grp P. Preferred reporting tems for systematic reviews and meta-analyses: The PRISMA Statement (Reprinted from Annals of Internal Medicine). Phys Ther. 2009;89:873-80.

19. Office International des Epizooties. OIE Handistatus II. 2018. http://web.oie int/hs2/report.asp?lang=en. Accessed 1 Apr 2018.

20. Office International des Epizooties. OIE World Animal Health Information Database (WAHIS). 2018. http://www.oie.int/wahis_2/public/wahid.php/ Wahidhome/Home/indexcontent/newlang/en. Accessed 1 Apr 2018

21. R Core Team. R: A language and environment for statistical computing. Vienna: R Foundation for Statistical Computing; 2018.

22. Wardrop NA, Thomas LF, Atkinson PM, de Glanville WA, Cook EAJ, Wamae $\mathrm{CN}$, et al. The influence of socio-economic, behavioural and environmental factors on Taenia spp. transmission in western Kenya: evidence from a cross-sectional survey in humans and pigs. PLoS Negl Trop Dis. 2015;9: e0004223.

23. Birrie H, Erko B, Tedla S. Intestinal helminthic infections in the southern Rift Valley of Ethiopia with special reference to schistosomiasis. East Afr Med J. 1994:71:447-52

24. Odongo AO, Moturi WN, Mbuthia EK. Heavy metals and parasitic geohelminths toxicity among geophagous pregnant women: a case study of Nakuru Municipality, Kenya. Environ Geochem Health. 2016;38:123-31.

25. Praet N, Verweij JJ, Mwape KE, Phiri IK, Muma JB, Zulu G, et al. Bayesian modelling to estimate the test characteristics of coprology, coproantigen ELISA and a novel real-time PCR for the diagnosis of taeniasis. Trop Med Int Heal. 2013;18:608-14.

26. Fèvre EM, de Glanville WA, Thomas LF, Cook EAJ, Kariuki S, Wamae CN. An integrated study of human and animal infectious disease in the Lake Victoria crescent small-holder crop-livestock production system, Kenya. BMC Infect Dis. 2017;17:457

27. Kumwenda S, Msefula C, Kadewa W, Diness Y, Kato C, Morse T, et al. Is there a difference in prevalence of helminths between households using ecological sanitation and those using traditional pit latrines? A latrine based cross sectional comparative study in Malawi. BMC Res Notes. 2017;10:200.

28. Trönnberg L, Hawksworth D, Hansen A, Archer C, Stenström TA. Householdbased prevalence of helminths and parasitic protozoa in rural KwaZuluNatal, South Africa, assessed from faecal vault sampling. Trans R Soc Trop Med Hyg. 2010;104:646-52.

29. Bordon L. Intestinal obstruction due to Taenia saginata infection: a case report. J Trop Med Hyg. 1990;95:352-3.

30. Tembo W, Nonga HE. A survey of the causes of cattle organs and/or carcass condemnation, financial losses and magnitude of foetal wastage at an abattoir in Dodoma, Tanzania. Onderstepoort J Vet Res. 2015;82:a855.
31. Phiri A. Common conditions leading to cattle carcass and offal condemnations at 3 abattoirs in the Western Province of Zambia and their zoonotic implications to consumers. J S Afr Vet Assoc. 2006;77:28-32.

32. Onyango-Abuje JA, Nginyi JM, Rugutt MK, Wright SH, Lumumba P, Hughes $\mathrm{G}$, et al. Seroepidemiological survey of Taenia saginata cysticercosis in Kenya. Vet Parasitol. 1996;64:177-85.

33. Kebede N, Tilahun G, Hailu A. Development and evaluation of indirect hemagglutination antibody test (IHAT) for serological diagnosis and screening of bovine cysticercosis in Ethiopia. Ethiop J Sci. 2008;31:135-40.

34. Kumar A, Berhe G. Occurrence of cysticercosis in cattle of parts of Tigray region of Ethiopia. Haryana Vet. 2008;47:88-90.

35. Assefa A, Tesfay H. Major causes of organ condemnation and economic loss in cattle slaughtered at Adigrat municipal abattoir, northern Ethiopia. Vet World. 2013;6:734-8.

36. Edo JJ, P M, Rahman MT. Investigation into major causes of organs condemnation in bovine slaughtered at Adama municipal abattoir and their economical importance. Haryana Vet. 2014;53:139-43.

37. Mummed Y. Beef carcass quality, yield and causes of condemnations in Ethiopia. PhD thesis, University of Pretoria; 2015.

38. Roche R, Bain R, Cumming O. A long way to go - estimates of combined water, sanitation and hygiene coverage for 25 sub-Saharan African countries. PLoS One. 2017;12:e0171783.

39. Braae UC, Saarnak CFL, Mukaratirwa S, Devleesschauwer B, Magnussen P, Johansen MV. Taenia solium taeniosis/cysticercosis and the co-distribution with schistosomiasis in Africa. Parasit Vectors. 2015;8:323.

40. Garcia HH, Nash TE, Del Brutto OH. The tapeworm that turned. Lancet Neurol. 2014;13:1173.

41. Havelaar A, Kirk M, Torgerson P, Gibb H, Hald T, Lake R, et al. World Health Organization global estimates and regional comparisons of the burden of foodborne disease in 2010. PLoS Med. 2015;12:e1001923.

42. Nash TE, Mahanty S, Garcia HH. Neurocysticercosis - more than a neglected disease. PLoS Negl Trop Dis. 2013;7:e1964.

43. WHO. Taenia solium taeniasis/cysticercosis diagnostic tools. Report of a stakeholder meeting. Geneva, 17-18 December 2015. Geneva: World Health Organization; 2016.

44. Abunna F, Tilahun G, Megersa B, Regassa A. Taeniasis and its socioeconomic implication in Awassa town and its surroundings, southern Ethiopia. East Afr J Public Health. 2007:4:73-9.

45. Regassa A, Abunna F, Mulugeta A, Megersa B. Major metacestodes in cattle slaughtered at Wolaita Soddo municipal abattoir, southern Ethiopia: prevalence, cyst viability, organ distribution and socioeconomic implications. Trop Anim Health Prod. 2009;41:1495-502.

46. Megersa B, Tesfaye E, Regassa A, Abebe R, Abunna F. Bovine cysticercosis in cattle slaughtered at Jimma municipal abattoir, South Western Ethiopia: prevalence, cyst viability and its socio-economic importance. Vet World. 2010;3:257-62.

47. Abunna F. Prevalence, orgain distribution, viability and socioeconomic implication of bovine cysticercosis/teniasis, Ethiopia. Rev Elev Med Vet Pays Trop. 2013;66:25-30.

48. Tadesse A, Tolossa YH, Ayana D, Terefe G. Bovine cysticercosis and human taeniosis in south-west Shoa zone of Oromia Region, Ethiopia. Ethiop Vet J. 2013;17:121-33.

49. Teklemariam AD, Debash W. Prevalence of Taenia saginata/cysticercosis and community knowledge about zoonotic cestodes in and around Batu, Ethiopia. J Vet Sci Technol. 2015;6:273.

50. Gasparinho C, Mirante MC, Centeno-Lima S, Istrate C, Mayer AC, Tavira L, et al. Etiology of diarrhea in children younger than 5 years attending the Bengo general hospital in Angola. Pediatr Infect Dis J. 2016;35:e28-34.

51. Nindia A, Moreno M, Salvador F, Amor A, de Alegría MLAR, Kanjala J, et al. Prevalence of Strongyloides stercoralis and other intestinal parasite infections in school children in a rural area of Angola: a cross-sectional study. Am J Trop Med Hyg. 2017;97:1226-31.

52. Fontanet A, Sahlu T, Rinke de Wit T, Messele T, Masho W, Woldemichael T, et al. Epidemiology of infections with intestinal parasites and human immunodeficiency virus (HIV) among sugar-estate residents in Ethiopia. Ann Trop Med Parasitol. 2000;94:269-78.

53. Berhanu M, Girmay E. Human helminthiasis in Wondo Genet Southern Ethiopia with emphasis on geohelminthiasis. Ethiop Med J. 2003:41:333-46.

54. Hailemariam G, Kassu A, Abebe G, Abate E, Damte D, Mekonnen E, et al. Intestinal parasitic infections in HIV/AIDS and HIV seronegative individuals in a teaching hospital, Ethiopa. Jpn J Infect Dis. 2004;57:41-3. 
55. Ramos JM, Rodríguez-Valero N, Tisiano G, Fano H, Yohannes T, Gosa A, et al. Different profile of intestinal protozoa and helminthic infections among patients with diarrhoea according to age attending a rural hospital in southern Ethiopia. Trop Biomed. 2014;31:392-7.

56. Terefe A, Shimelis T, Mengistu M, Hailu A, Erko B. Schistosomiasis mansoni and soil-transmitted helminthiasis in Bushulo Village, southern Ethiopia. Ethiop J Heal Dev. 2011;25:46-50.

57. Abay G, Kumar A. Cysticercosis in cattle and its public health implications in Mekelle City and surrounding areas, Ethiopia. Ethiop Vet J. 2013;17:31-40.

58. Fekadu S, Taye K, Teshome W, Asnake S. Prevalence of parasitic infections in HIV-positive patients in southern Ethiopia: a cross-sectional study. J Infect Dev Ctries. 2013;7:868-72.

59. Mamo H. Intestinal parasitic infections among prison inmates and tobacco farm workers in Shewa Robit, north-central Ethiopia. PLoS One. 2014;9:e99559.

60. Abera B, Biadegelgen F, Bezabih B. Prevalence of Salmonella typhi and intestinal parasites among food handlers in Bahir Dar Town, northwest Ethiopia. Ethiop J Heal Dev. 2010;24:46-50.

61. Wegayehu T, Tsalla T, Seifu B, Teklu T. Prevalence of intestinal parasitic infections among highland and lowland dwellers in Gamo area, South Ethiopia. BMC Public Health. 2013;13:151.

62. Dagnew M, Tiruneh M, Moges F, Tekeste Z. Survey of nasal carriage of Staphylococcus aureus and intestinal parasites among food handlers working at Gondar University, northwest Ethiopia. BMC Public Health. 2012;12:837.

63. Beyene G, Tasew H. Prevalence of intestinal parasite, Shigella and Salmonella species among diarrheal children in Jimma health center. Jimma southwest Ethiopia: a cross sectional study. Ann Clin Microbiol Antimicrob. 2014;13:10.

64. Aklilu A, Kahase D, Dessalegn M, Tarekegn N, Gebremichael S, Zenebe S, et al. Prevalence of intestinal parasites, Salmonella and Shigella among apparently health food handlers of Addis Ababa University student's cafeteria, Addis Ababa, Ethiopia. BMC Res Notes. 2015:8:17.

65. Mengist HM, Taye B, Tsegaye A. Intestinal parasitosis in relation to CD4+T cells levels and anemia among HAART initiated and HAART naive pediatric HIV patients in a model ART center in Addis Ababa, Ethiopia. PLoS One. 2015;10:e0117715.

66. Alemayehu B, Tomass Z, Wadilo F, Leja D, Liang S, Erko B. Epidemiology of intestinal helminthiasis among school children with emphasis on Schistosoma mansoni infection in Wolaita zone, southern Ethiopia. BMC Public Health. 2017;17:587.

67. Alemu G, Mama M. Intestinal helminth co-infection and associated factors among tuberculosis patients in Arba Minch, Ethiopia. BMC Infect Dis. 2017; $17: 68$

68. Nyantekyi L, Legesse M, Medhin G, Animut A, Tadesse K, Macias C, et al. Community awareness of intestinal parasites and the prevalence of infection among community members of rural Abaye Deneba area, Ethiopia. Asian Pac J Trop Biomed. 2014;4:S152-7.

69. Kagira JM, Maina N, Njenga J, Karanja SM, Karori SM, Ngotho JM. Prevalence and types of coinfections in sleeping sickness patients in Kenya (2000/2009). J Trop Med. 2011;2011:248914.

70. Kipyegen CK, Shivairo RS, Odhiambo RO. Prevalence of intestinal parasites among HIV patients in Baringo, Kenya. Pan Afr Med J. 2012;13:37.

71. Buchy P. Les parasitoses digestives dans la région de Mahajanga, côte Ouest de Madagascar. Bull La Soc Pathol Exot. 2003;96:41-5.

72. Du Plooy I. Results of routine examinations for parasitic infections of humans from laboratory-submitted samples in Gauteng, North West and Mpumalanga provinces between 2009 and 2010. MSc thesis: University of Pretoria; 2014

73. Nxasana N, Baba K, Bhat V, Vasaikar S. Prevalence of intestinal parasites in primary school children of Mthatha, Eastern Cape Province, South Africa. Ann Med Health Sci Res. 2013;3:511-6.

74. Taylor M, Pillai G, Kvalsvig JD. Targeted chemotherapy for parasite infestations in rural black preschool children. South African Med J. 1995:85:870-4.

75. Eom KS, Chai JY, Yong TS, Min DY, Rim HJ, Kihamia C, et al. Morphologic and genetic identification of Taenia tapeworms in Tanzania and DNA genotyping of Taenia solium. Korean J Parasitol. 2011;49:399-403.

76. Kabatereine N, Kemijumbi J, Kazibwe F, Onapa A. Human intestinal parasites in primary school children in Kampala, Uganda. East Afr Med J. 1997;74:311-4.

77. Siwila J, Phiri IGK, Enemark HL, Nchito M, Olsen A. Intestinal helminths and protozoa in children in pre-schools in Kafue district, Zambia. Trans R Soc Trop Med Hyg. 2010;104:122-8.

78. Tembo A. Detection and diagnosis of Taenia saginata taeniosis. PhD thesis, University of Salford, UK; 2010.
79. Cook EA. Epidemiology of zoonoses in slaughterhouse workers in western Kenya. PhD thesis, University of Edinburgh, UK; 2014.

80. Skjerve E. Possible increase of human Taenia saginata infections through import of beef to Norway from a high prevalence area. J Food Prot. 1999; 62:1314-9.

81. Kebede N, Tilahun G, Hailu A. Current status of bovine cysticercosis of slaughtered cattle in Addis Ababa abattoir, Ethiopia. Trop Anim Health Prod. 2009;41:291-4.

82. Kebede N. Cysticercosis of slaughtered cattle in northwestern Ethiopia. Res Vet Sci. 2008;85:522-6.

83. Abunna F, Tilahun G, Megersa B, Regassa A, Kumsa B. Bovine cysticercosis in cattle slaughtered at Awassa municipal abattoir, Ethiopia: prevalence, cyst viability, distribution and its public health implication. Zoonoses Public Health. 2008;55:82-8

84. Tolosa T, Tigre W, Teka G, Dorny P. Prevalence of bovine cysticercosis and hydatidosis in Jimma municipal abattoir, South West Ethiopia. Onderstepoort J Vet Res. 2009;76:323-6.

85. Belay S. Prevalence of Cysticercus bovis in cattle at municipal abbatoir of Shire. J Vet Sci Technol. 2014;5:196.

86. Kang'ethe EK. The impact of meat inspection on the control of bovine hydatidosis in Kenya. Bull Anim Heal Prod Africa. 1995;63:261-8.

87. Asaava LL, Kitala PM, Gathura PB, Nanyingi MO, Muchemi G, Schelling E. A survey of bovine cysticercosis/human taeniosis in Northern Turkana District, Kenya. Prev Vet Med. 2009;89:197-204.

88. Onyango-Abuje JA, Hughes G, Opicha M, Nginyi KM, Rugutt MK, Wright SH, et al. Diagnosis of Taenia saginata cysticercosis in Kenyan cattle by antibody and antigen ELISA. Vet Parasitol. 1996;61:221-30.

89. Shikongo-Kuvare LT. Development of risk communication strategies to improve control of Cysticercosis bovis in north-central Namibia. MSc thesis: University of Pretoria, South Africa; 2007.

90. Ndou R, Dlamini M. The control of measles (bovine cysticercosis (Taenia saginata)) from South African feedlot cattle: where do we come from, where are we now and where are we going with control and prevention programmes against this zoonosis. Proceedings of the 10th Annual Congress of the Southern African Society for Veterinary Epidemiology and Preventive Medicine, Pretoria, South Africa; 2012.

91. Qekwana DN, Oguttu JW, Venter D, Odoi A. Disparities in beef tapeworm identification rates in the abattoirs of Gauteng Province, South Africa: a descriptive epidemiologic study. PLoS One. 2016;11:e0151725.

92. Kambarage DM, Kimera SI, Kazwala RR, Mafwere BM. Disease conditions responsible for condemnation of carcasses and organs in short-horn Zebu cattle slaughtered in Tanzania. Prev Vet Med. 1995;22:249-55.

93. Swai ES, Schoonman L. A survey of zoonotic diseases in trade cattle slaughtered at Tanga city abattoir: a cause of public health concern. Asian Pac J Trop Biomed. 2012;2:55-60.

94. Mellau BL, Nonga HE, Karimuribo ED. Slaughter stock abattoir survey of carcasses and organ/offal condemnations in Arusha region, northern Tanzania. Trop Anim Health Prod. 2011;43:857-64.

95. Komba EVG, Komba EV, Mkupasi EM, Mbyuzi AO, Mshamu S, Luwumba D, et al. Sanitary practices and occurrence of zoonotic conditions in cattle at slaughter in Morogoro municipality, Tanzania: implications for public health. Tanzan J Health Res. 2012;14:131-8.

96. Maeda GE, Kyvsgaard NC, Nansen P, Bøgh HO. Distribution of Taenia saginata cysts by muscle group in naturally infected cattle in Tanzania. Prev Vet Med. 1996;28:81-9.

97. Sungirai M, Masaka L, Mbiba C. The prevalence of Taenia saginata cysticercosis in the Matabeleland provinces of Zimbabwe. Trop Anim Health Prod. 2014;46:623-7

98. Tsotetsi-Khambule AM, Niiro S, Katsande TC, Thekisoe OMM, Harrison LS. Sero-prevalence of Taenia spp. infections in cattle and pigs in rural farming communities in Free State and Gauteng provinces, South Africa. Acta Trop. 2017;172:91-6.

99. Hughes $\mathrm{G}$, Hoque M, Tewes MS, Wright SH, Harrison LJS. Seroepidemiological study of Taenia saginata cysticercosis in Swaziland. Res Vet Sci. 1993:55:287-91.

100. Dorny P, Phiri I, Gabriël S, Speybroeck N, Vercruysse J. A sero-epidemiological study of bovine cysticercosis in Zambia. Vet Parasitol. 2002;104:211-5. 